\title{
Pelaksanaan Program Ahlul Qur'an (PRO-AQ) Sebagai Sarana Percepatan Hafalan di Rumah Qur'an Al-Azhar Al-Syarif Kertak Hanyar Kalsel
}

\author{
Muhammad Iqbal Ansari ${ }^{1}$, Iman Setya Budi ${ }^{2}$ \\ Program Studi PGMI UNISKA Muhammad Arsyad Al Banjari Banjarmasin \\ Email: ${ }^{1}$ muhammadiqbalansari13@gmail.com, ${ }^{2}$ aymannoordin@gmail.com
}

\begin{abstract}
Based on Sofyan's research entitled Development of the Tahfiz Qur'an Movement in the Reformation Era in Indonesia, tahfizh Al-Qur'an learning is growing. It can be seen from the rapid development of Rumah Tahfizh which was triggered by Daarul Qur'an which was initiated by Yusuf Mansur which reached 300 more branches. The concept of Rumah Tahfizh was adopted by Al-Qur'an educational institutions in Indonesia, instead of the AlAzhar Al-Syarif Qur'an House which was installed in Manarap Village, Banjar Regency, South Kalimantan Province. Based on the results of observations, learning at Al-Azhar Al-Syarif Qur'an House is carried out in 3 shifts, namely shift 1, shift 2, and the afternoon shift. Each shift was conducted 3 times in the discussion. Expect students to actively study in 1 week 3 times. The target of students to memorize each visit is 2 lines of the Al-Qur'an Standard Mushaf Madinah. But this target failed to be resolved due to several problems, in the approval of students not entering (permission or illness), strengthening memorization that had been deposited, still the process of developing reading improvements, or new students memorizing composting at the Qur'an House not at home. One of the alternatives to maximize the memorization of the Qur'an is the program held by Tahfidzh Quarantine 1 Day at Al-Azhar Al-Syarif Qur'an House. The purpose of quarantine tahfidzh 1 day is to accelerate memorization, and activities at school after quarantine is muroja'ah, which is repetition of memorization that has been completed by compiling quarantine programs, has improved memorization, learning will be efficient, both for improving memorization and reading.
\end{abstract}

Key Words: Quarantine, Ahlul Qur'an, Tahfidzh, Memorizing

\section{Pendahuluan}

Perkembangan pembelajaran tahfizh Al-Qur'an pada dasawarsa terakhir semakin pesat. Hal ini berdasarkan penelitian Sofyan yang bertajuk The Development of Tahfiz Qur'an Movement in The Reform Era in Indonesia. Dalam penelitian tersebut dikemukakan bahwa salah satu indikator pesatnya 
perkembangan kegiatan menghafal Al-Qur'an di Indonesia ialah munculnya Rumah Tahfizh yang dicetuskan oleh Daarul Qur'an yang diinisiasi oleh Yusuf Mansur. Terdapat hingga 300 buah lembaga di Indonesia yang dinaungi oleh Rumah Tahfizh Daarul Qur'an. ${ }^{1}$

Sistem Rumah Tahfidzh ini hampir sama dengan lembaga pendidikan dayah Tahfizd Ulumul Qur'an yang ada di Banda Aceh. Kedua lembaga ini sama-sama memfokuskan peserta didik untuk menghafal al-Qur'an. Proses menghafal Al-Qur'an dimulai pada sore atau malam hari, setelah para peserta didik selesai mengikuti kegiatan sekolah formal. ${ }^{2}$

Berbeda dengan pondok pesantren, Rumah Tahfiz didirikan dengan konsep "jemput bola”, hadir di tengah-tengah masyarakat muslim, sehingga mereka dapat dengan mudah untuk mengembangkan potensi anak-anak mereka dalam menghafal Al-Qur'an. Dan konsep Rumah Tahfizh ini yang kemudian diadopsi oleh lembaga-lembaga pendidikan Al-Qur'an di Indonesia, diantaranya adalah Rumah Qur'an Al-Azhar Al-Syarif yang berlokasi di Desa Manarap, Kabupaten Banjar, Provinsi Kalimantan Selatan.

Berdasarkan hasil observasi, pembelajaran di Rumah Qur'an Al-Azhar Al-Syarif dilaksanakan dalam 3 shift, yaitu shift 1, shift 2, dan shift sore. Setiap shift dilaksanakan 3 kali dalam seminggu. Artinya peserta didik aktif belajar dalam 1 minggu sebanyak 3 kali. Berikut adalah jadwal pembelajaran di Rumah Qur'an Al-Azhar Al-Syarif:

1. Shift 1 : Malam Minggu, Selasa, dan Kamis

2. Shift 2 : Malam Senin, Rabu, dan Jum'at

3. Shift Sore : Sore Senin, Rabu, dan Jum'at

1 Sofyan, M. The Development of Tahfiz Qur'an Movement in The Reform Era in Indonesia. International Journal of Religious Literature and Heritage , 4(1),115-136, 2015.

2 Barri, F. Manajemen Waktu Santri di Dayah Tahfidz Ulumul Qur'an Pagar Air Banda Aceh. Jurnal Ilmiah Didaktika, 17(1), 138-265, 2016. 
Target peserta didik untuk menghafal setiap harinya ialah 2 baris AlQur'an Standar Mushaf Madinah. Sehingga jika ditotalkan, maka peserta didik mampu menghafal 6 baris dalam seminggu ( 3 kali pertemuan) atau setengah halaman. Berarti dalam 1 bulan target hafalan adalah 24 baris atau 2 halaman.

Namun target ini terkadang tidak tercapai karena beberapa permasalahan, di antaranya peserta didik tidak masuk (izin atau sakit), penguatan hafalan yang telah disetorkan, masih proses tahapan perbaikan bacaan, atau peserta didik baru menghafal ketika berada di Rumah Qur'an bukan di rumah, sehingga terkadang target 2 baris tidak tercapai dan kurang mantap.

Melihat hal-hal di atas, sangat penting kiranya mencari solusi agar peserta didik dapat fokus untuk menghafal dan mencapai target yang direncanakan, terutama dalam menghafal Al-Qur'an surah-surah Juz 'Amma yang sekarang sudah banyak diwajibkan di beberapa beberapa institusi pendidikan sekolah dasar.

Alternatif untuk memaksimalkan kegiatan menghafal Al-Qur'an tersebut adalah diadakannya program Karantina Tahfidzh 1 Hari atau yang kemudian diberi nama Program Ahlul Qur'an (Pro-Aq) di Rumah Qur'an Al-Azhar AlSyarif Desa Manarap Tengah. Karantina Tahfidzh 1 Hari di Rumah Tahfidzh Al-Haramain yang terletak di Kelurahan Pekapuran Kota Banjarmasin. Dari penelitian tersebut ditemukan bahwa hasil capaian hafalan anak usia SD/MI paling tinggi sebanyak 62 baris, atau 4 halaman 2 baris, yang berarti peserta tersebut rata-rata menyetorkan hafalan 15 baris Al-Qur'an dalam sekali sesi setoran. Peserta yang mencapai hafalan sebanyak ini ialah peserta yang duduk di kelas V (2 orang) dan kelas VI (1 orang). Sedangkan paling sedikit peserta menghafal 30 baris atau 2 halaman. Capaian hafalan hingga 30 baris merupakan yang paling banyak dicapai, yaitu 17 orang, artinya dari 4 kali sesi setoran, rata-rata mereka menyetor hafalan sebanyak 7-8 baris dalam 1 
kali sesi setoran Al-Qur'an. Artinya ada peningkatan hafalan peserta didik dalam 1 hari jika mereka difokuskan untuk menggeluti Al-Qur'an. ${ }^{3}$

Tujuan karantina tahfidzh 1 hari adalah untuk percepatan hafalan, dan kegiatan di sekolah setelah karantina adalah ialah muroja'ah, yaitu mengulang hafalan yang telah disetorkan ketika program karantina, sehingga karena telah hafal, waktu pembelajaran akan menjadi efisien. Selain itu, kegiatan ini bukan hanya berisi kegiatan menghafal, namun juga dilengkapi dengan motivating, Ice Breaking, dan game untuk meningkatkan motivasi dan semangat peserta didik untuk menghafal.

\section{Metode}

Pelaksanaan kegiatan pengabdian kepada masyarakat ini dilaksanakan dalam 3 tahap yaitu : tahap persiapan, tahap pelaksanaan dan tahap evaluasi.

1. Tahap Persiapan

Persiapan yang dilaksanakan pada pengabdian ini dilaksanakan dalam beberapa langkah:

a. Mendatangi lokasi mitra Rumah Qur'an Al-Azhar Al-Syarif di Desa Manarap Tengah melakukan observasi dan wawancara pada tanggal 38 Februari 2019

b. Melakukan rapat persiapan dengan pembentukan kepanitian serta penentuan waktu kegiatan pada tanggal 14 Februari 2019

c. Menyampaikan waktu kegiatan dan membagikan formulir pendaftaran dari tanggal 17-22 Februari 2019

d. Melaksanakan rapat akhir persiapan pada tanggal 22 Februari 2019 dengan merekap jumlah peserta, baik itu putera dan puteri.

e. Pelaksanaan kegiatan pada tanggal 24 Februari 2019.

${ }^{3}$ Ansari, Muhammad Iqbal. Sistem Karantina Tahfidzh 1 Hari untuk Anak Usia SD/MI di Rumah Tahfidzh Al-Haramain. Jurnal Al Ibtida, IAIN Syekh Nurjati, Vol 5 (2) : 205-220, 2018. 
2. Tahap Pelaksanaan

Karantina Tahfidzh 1 Hari dilaksanakan pada hari minggu yang diikuti oleh peserta didik Rumah Qur'an Al-Azhar Al-Syarif. Kegiatan karantina ini dilaksanakan dengan penerapan beberapa program, yaitu program inti dan program pelengkap.

a. Program inti. Kegiatan inti yang dijalankan ialah setoran hafalan. Metode setoran untuk peserta karantina usia SD/MI menggunakan metode fardi. Tingkat kemampuan peserta dibagi kepada 2, yaitu tahfizh dan tahsin. Tahfizh merupakan kelompok yang terdiri dari santri yang bacaan Al-Qur'an sudah baik dan lancar, sesuai dengan kaidah tajwid. Sedangkan tahsin merupakan kelompok yang terdiri dari santri yang bacaan Al-Qur'an masih perlu pengawasan dan perbaikan.

b. Program pelengkap. Merupakan kegiatan tambahan berupa olahraga ringan seperti senam ringan pada pagi hari untuk menyemangati para peserta. Kegiatan motivating dan ice breaking yang bertujuan untuk meningkatkan kembali motivasi peserta dalam menghafal Al-Qur'an.

\section{Evaluasi Kegiatan}

Guna mengetahui efektifitas kegiatan Pro-Aq ini, evaluasi yang dilakukan pengumpulan hasil setoran peserta didik dari para muhafidzh, dan kemudian divisi acara merekap capaian hafalan peserta didik yang paling banyak dari masing-masing muhafidz kemudian memilih peserta terbaik dengan kategori 1, 2, dan 3 dari putera dan puteri.

Selain itu dilaksanakan pula evaluasi kegiatan dengan rapat panitia dengan melihat proses pelaksanaan dan kendala-kendala yang dihadapi.

\section{Hasil Dan Diskusi}

Guna memaksimalkan kegiatan, peneliti menyusun tiga langkah dalam pelaksanaan pengabdian pro, yaitu prapengabdian, pengabdian, dan pasca pengabdian. 
1. Prapengabdian

Guna mengetahui permasalahan mitra, langkah pertama yang dilakukan adalah melakukan observasi dan wawancara kepada pihak mitra. Observasi dilakukan dengan mengamati pembelajaran yang dilaksanakan di RQ Al-Azhar Al-Syarif, baik itu pada shift 1, 2, dan sore.

Wawancara dilakukan untuk mengkonfirmasi hasil observasi dan menggali mengenai kendala yang dihadapi oleh guru. Kemudian disusun suatu rencana bersama pihak mitra untuk memecahkan masalah yang dihadapi. Dan diputuskan dengan melaksanakan program Karantina Tahfidzh 1 Hari.

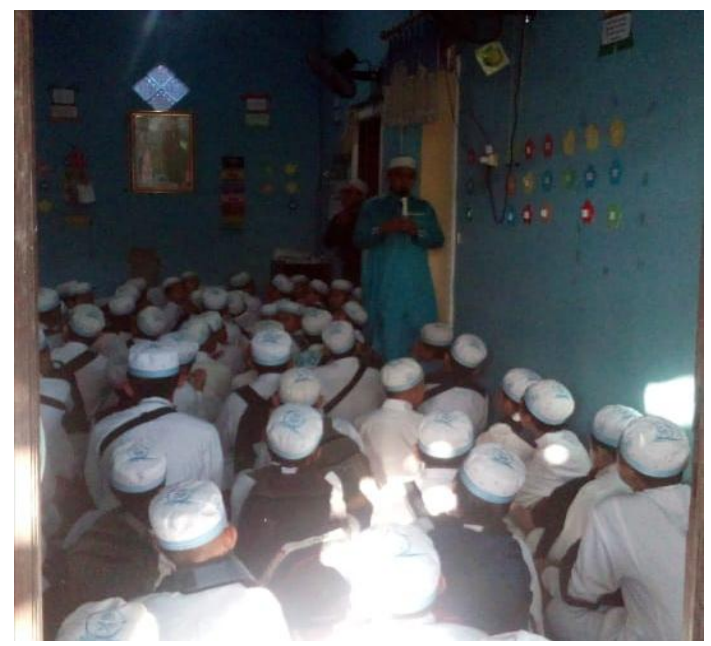

\section{Gambar 1. Pengarahan Santri (Sumber: Dokumentasi, 2019)}

Proses sebelum pelaksanaan, dibentuk kepanitian program, dari Ketua, Sekretaris, Bendahara, dan beberapa divisi, yaitu divisi Acara, divisi Konsumsi, dan Muhafidzh (Guru penerima setoran hafalan).

Panitia para hari berikutnya mengumumkan program Karantina 1 Hari dan membagikan formulir pendaftaran kepada peserta didik. Satu hari menjelang pelaksanaan, panitia membentuk kelompok peserta didik dengan 11 orang dalam 1 kelompok yang akan ditangani oleh seorang muhafidzh. 
Dipersiapkan pula lembar isian untuk merekam hasil hafalan peserta didik selama mengikuti karantina 1 hari. Kemajuan hafalan dinilai berdasarkan baris Al-Qur'an. Jika peserta didik menyelesaikan setoran sebanyak 15 baris, berarti dia sudah menyelesaikan 1 halaman. Isian ini akan diisi oleh masing-masing muhafidzh.

\section{Pengabdian}

Kegiatan pengabdian kepada masyarakat ini dilaksanakan pada tanggal 24 Februari 2019 yang dimulai pada pukul 07.30 sampai dengan pukul 14.00 WITA, bertempat di Rumah Qur'an Al-Azhar Al-Syarif untuk peserta didik puteri dan Langgar Makanut Thalibin untuk peserta didik putera yang beralamat di Gang Mentari Desa Manarap Tengah, Kecamatan Kertak Hanyar Kabupaten Banjar. Kegiatan Karantina Tahfidzh 1 Hari dikuti oleh 51 peserta putera dan 58 peserta puteri, dengan total keseluruhan 109 peserta. Proses pelaksanaan kegiatan dapat diamati pada Tabel 1. berikut:

Tabel 1. Pelaksanaan Kegiatan Pengabdian

\begin{tabular}{|c|c|l|}
\hline No & Waktu & \multicolumn{1}{c|}{ Kegiatan } \\
\hline 1 & $07.30-08.00$ & $\begin{array}{l}\text { Berkumpul dan senam } \\
\text { Checking dan pembagian kelompok peserta. Kemudian } \\
\text { senam ringan untuk memberikan efek relax. Selanjutnya } \\
\text { pengarahan dan pembimbingan peserta untuk menuju } \\
\text { tempat kelompoknya. }\end{array}$ \\
\hline 2 & $08.00-09.00$ & $\begin{array}{l}\text { Setoran 1 } \\
\text { Setoran dilaksanakan denga metode fardy, yaitu peserta } \\
\text { disusun secara berbaris ke belakang kemudian maju 1 per } \\
\text { 1 ke hadapan muhafidz untuk menyetorkan hafalan. Bagi } \\
\text { peserta yang bacaan masih kurang tepat, maka } \\
\text { menyetorkan bacaan ayat dulu kepada muhafidz baru } \\
\text { kemudian kembali ke barisan paling belakang dan } \\
\text { menghafal ayat yang sudah disetorkan bacaannya } \\
\text { sementara menunggu giliran. }\end{array}$ \\
\hline 3 & $09.00-09.15$ & $\begin{array}{l}\text { Snacking } \\
\text { Panitia membagikan snack seperti kue dan kerupuk kepada } \\
\text { peserta. Air mineral sudah disediakan sejak awal kegiatan. }\end{array}$ \\
\hline 4 & $09.15-10.15$ & $\begin{array}{l}\text { Setoran 2 } \\
\text { Prosesi sama dengan setoran 1 }\end{array}$ \\
\hline
\end{tabular}




\begin{tabular}{|c|c|l|}
\hline No & Waktu & \multicolumn{1}{c|}{ Kegiatan } \\
\hline 5 & $10.15-11.00$ & $\begin{array}{l}\text { Motivating dan Snacking } \\
\text { Divisi Acara mengajak peserta untuk sedikit senam ringan } \\
\text { seperti menggerak-gerakkan tangan, memijat pundak } \\
\text { kawan yang di depan sebagai relaksasi. Kemudian } \\
\text { pembagian snack dan dilanjutkan dengan ceramah tentang } \\
\text { keutamaan menghafal Al-Qur'an dari salah seorang guru. }\end{array}$ \\
\hline 6 & $11.00-11.45$ & $\begin{array}{l}\text { Murajaah Setoran 1 dan 2 } \\
\text { Sama halnya dengan prosesi setoran 1 dan 2, namun yang } \\
\text { berbeda pada sesi ini ialah hafalan yang disetorkan adalah } \\
\text { mengulang hasil hafalan yang disetorkan pada Setoran 1 } \\
\text { dan Setoran 2. }\end{array}$ \\
\hline 7 & $11.45-12.45$ & $\begin{array}{l}\text { Ice Breaking dan Game } \\
\text { Kegiatan ini diisi dengan membacakan yel-yel RQ Al-Azhar } \\
\text { Al-Syarif dan diisi dengan game tebak-tebakan seperti } \\
\text { menyambung ayat, hadits, dan pengetahuan lainnya yang } \\
\text { diajarkan pada materi ta'lim. }\end{array}$ \\
\hline 8 & $12.45-13.00$ & $\begin{array}{l}\text { Shalat Dhuhur } \\
\text { Shalat dhuhur dilaksanakan secara berjamaah di langgar } \\
\text { Makanut Thalibin untuk peserta putera. Sedangkan peserta } \\
\text { puteri melaksanakan shalat dhuhur di ruang kelas. }\end{array}$ \\
\hline 9 & $13.00-13.30$ & $\begin{array}{l}\text { Makan Siang } \\
\text { Peserta dibimbing untuk berkumpul di ruang utama RQ Al- } \\
\text { Azhar Al-Syarif. Kemudian tempat duduk diatur } \\
\text { sedemikian rupa untuk prosesi pembagian makanan dan } \\
\text { prosesi penyerahan penghargaan. }\end{array}$ \\
\hline 10 & $13.30-14.00$ & $\begin{array}{l}\text { Pemberian Reward dan Penutup } \\
\text { Pada akhir acara diumumkan peserta yang meraih hafalan } \\
\text { terbanyak dan kemudian diberikan penghargaan berupa } \\
\text { tropi dan sertifikat. Kemudian dilanjutkan dengan doa oleh } \\
\text { salah seorang guru dan ditutup dengan doa senandung Al- } \\
\text { Qur'an yang dibaca bersama-sama oleh peserta. }\end{array}$ \\
\hline
\end{tabular}

Sumber: Dokumentasi Pengabdian, 2019

\section{Pascapengabdian}

Guna mengetahui efektifitas kegiatan, evaluasi yang dilakukan pengumpulan hasil setoran peserta didik dari para muhafidzh, dan kemudian divisi acara merekap capaian hafalan peserta didik yang paling banyak dari masing-masing muhafidz kemudian memilih peserta terbaik dengan kategori 1, 2, dan 3 dari putera dan puteri. 

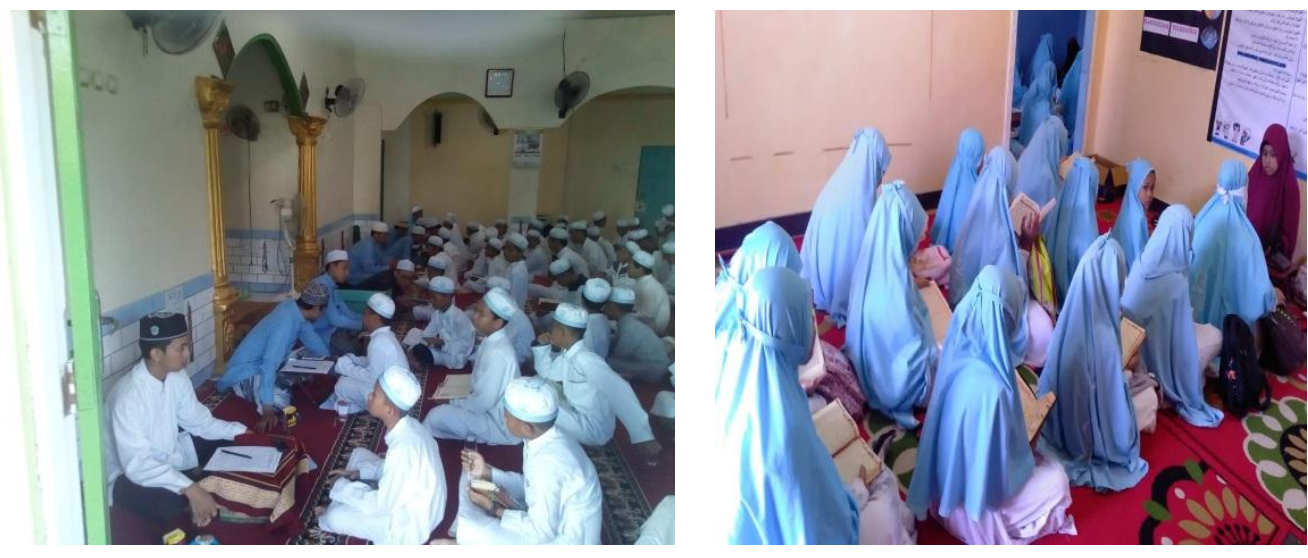

\section{Gambar 2. Prosesi Setoran Putera dan Puteri (Sumber: Dokumentasi, 2019)}

Adapun peserta terbaik putera tingkat MI/SD diraih oleh Muhsin Labib dengan capaian 30 baris atau 2 halaman. Sedangkan peserta terbaik puteri diraih oleh Naysiela Bilqis dengan capaian 37 baris atau 2 halaman 7 baris. Berikut adalah rekap hasil capaian peserta pada Tabel 2.

\section{Tabel 2. Rekapitulasi Hasil Capaian Peserta Pengabdian}

\begin{tabular}{|c|c|c|c|}
\hline \multirow{2}{*}{ No } & \multirow{2}{*}{$\begin{array}{c}\text { CAPAIAN HAFALAN } \\
\text { (dalam halaman) }\end{array}$} & \multicolumn{2}{|c|}{ JUMLAH } \\
\cline { 3 - 4 } & Laki-laki & Perempuan \\
\hline 1 & 2 halaman (23-30 baris) & 4 & 2 \\
\hline 2 & $11 / 2$ halaan (16-22 baris) & 11 & 8 \\
\hline 3 & 1 halaman (8-15 baris) & 22 & 35 \\
\hline 4 & $1 / 2$ halaman (6-7 baris) & 10 & 11 \\
\hline 5 & $1 / 3$ halaman (1-5 baris) & 4 & 2 \\
\hline \multicolumn{2}{|c|}{ Total } & 51 & 58 \\
\hline
\end{tabular}

Sumber: Dokumentasi Pengabdian, 2019

Berdasarkan hasil data di atas, didapati bahwa capaian hafalan terbanyak adalah antara 8-15 baris dengan jumlah 57 peserta didik yang mencapainya. Sedangkan yang paling sedikit adalah 23-30 yaitu sejumlah 6 orang. 


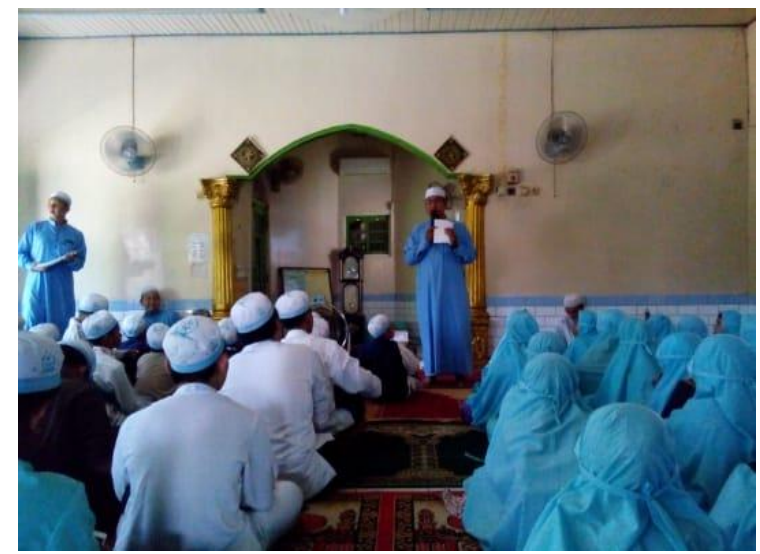

\section{Gambar 4. Pemberian Motivasi (Sumber: Dokumentasi, 2019)}

Refleksi yang dilakukan peneliti menyimpulkan bahwa peserta didik yang capaian hafalannya paling banyak adalah peserta didik yang sudah memiliki kemampuan membaca sangat baik, atau sudah sesuai dengan kaidah tajwid.

Berdasarkan hasil pelaksanaan kegiatan, didapati bahwa pelaksanaan kegiatan memberikan dampak positif bagi peserta didik, yaitu bertambahnya hafalan dan meningkatkan motivasi mereka dalam menghafal. Namun terdapat beberapa kendala dalam pelaksanaan kegiatan ini yang nanti bisa menjadi bahan refleksi bagi pelaksanaan berikutnya, yaitu:

a. Terdapat peserta yang memerlukan perhatian khusus, di antaranya peserta yang terlalu banyak bergurau dan peserta yang kemampuan membaca Al-Qur'an-nya masih kurang.

b. Tidak ada ruangan yang cukup dan kondusif untuk menampung jumlah peserta sebanyak itu. Menggunakan langgar terbatas untuk putera, karena jika puteri digabung maka ketika shalat dhuhur langgar tidak akan muat. Selain itu kondisi pendingin langgar yang terbatas, membuat suhu ruangan terasa panas. 
c. Karena lokasi yang terpisah, panitia kerepotan untuk memonitoring kegiatan karena jarak antara ruang kelas RQ Al-Azhar Al-Syarif dengan langgar dibatasi jalanan, sehingga perlu waktu, tenaga, dan kehatihatian untuk mengontrol jalannya kegiatan.

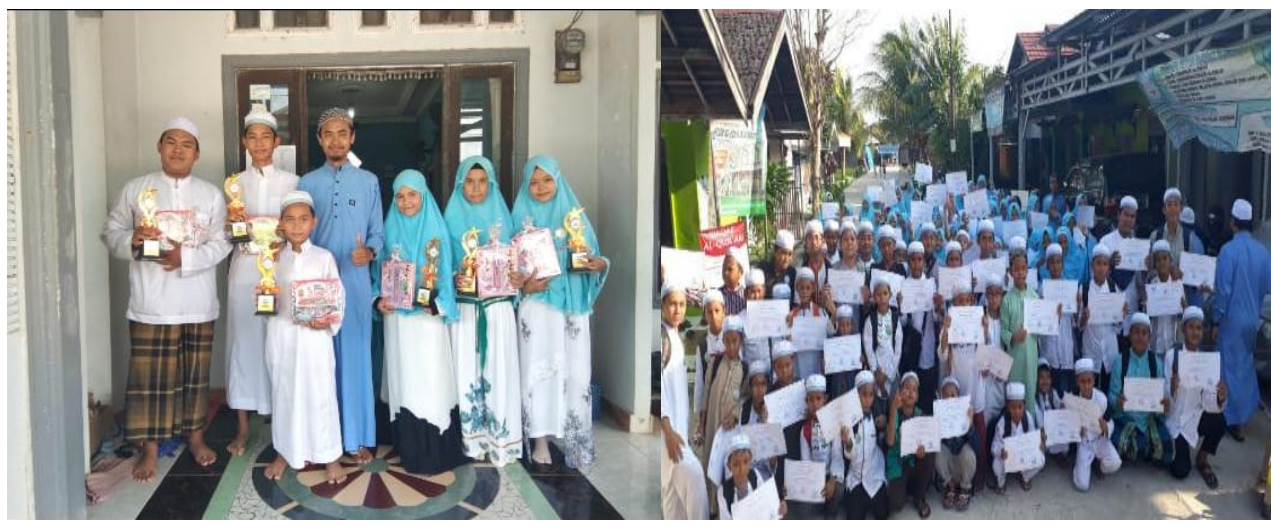

Gambar 5. Pemberian Penghargaan dan Sertifikat (Sumber: Dokumentasi, 2019)

Pengabdian masyarakat ini memberikan dampak yang positif bagi peserta didik Rumah Qur'an Al-Azhar Al-Syarif Desa Manarap Tengah, Kecamatan Kertak Hanyar, Kabupaten Banjar, Provinsi Kalimantan Selatan. Dampak positif tersebut ialah bertambahnya hafalan mereka dari segi kuantitas. Dan peserta didik juga mendapat motivasi dalam kegiatan ini.

Untuk meningkatkan kualitas hafalan yang didapat ketika Pro-Aq, masa 3 kali pertemuan setelah kegiatan tersebut digunakan untuk muraajaah atau mengulang hafalan. Kendala-kendala yang ditemukan hendaknya akan menjadi refleksi guna pelaksanaan pengabdian berikutnya sehingga akan menjadi semakin baik. 


\section{Simpulan}

Capaian hafalan terbanyak adalah antara 8-15 baris dengan jumlah 57 peserta didik yang mencapainya. Sedangkan yang paling sedikit adalah 23-30 yaitu sejumlah 6 orang. Pengabdian masyarakat ini memberikan dampak yang positif bagi peserta didik Rumah Qur'an Al-Azhar Al-Syarif Desa Manarap Tengah, Kecamatan Kertak Hanyar, Kabupaten Banjar, Provinsi Kalimantan Selatan.

\section{Daftar Referensi}

Ansari, Muhammad Iqbal. Pelaksanaan Karantina Tahfidzh 30 Hari untuk Anak Usia SD/MI. Jurnal Muallimuna: PGMI Fak.Studi Islam UNISKA MAB Banjarmasin, 2016.

Ansari, Muhammad Iqbal. Sistem Karantina Tahfidzh 1 Hari untuk Anak Usia SD/MI di Rumah Tahfidzh Al-Haramain. Jurnal Al Ibtida, IAIN Syekh Nurjati, Vol 5 (2) : 205-220, 2018.

Barri, F. Manajemen Waktu Santri di Dayah Tahfidz Ulumul Qur'an Pagar Air Banda Aceh. Jurnal Ilmiah Didaktika, 17(1), 138-265, 2016.

Sofyan, M. The Development of Tahfiz Qur'an Movement in The Reform Era in Indonesia. International Journal of Religious Literature and Heritage, 4(1),115-136, 2015.

Tim Yayasan Muntada Islami. Panduan Mengelola Sekolah Tahfizh. Surakarta: Al-Qowam, 2012. 